\title{
FOREIGN DIRECT INVESTMENT AND FOREIGN EXCHANGE RATE FLUCTUATIONS IN NIGERIA: 1981-2018
}

\begin{abstract}
OKONKWO, IKEOTUONYE VICTOR
Dr Okonkwo is an associate professor in the Department of Banking and Finance, Nnamdi Azikiwe University, Awka Anambra State, Nigeria. His research interests include Economic development, Stock Market Operations, Risk Management, Insurance and Financial Management. (Phone: +2348064258055)
\end{abstract}

\section{UKOH, JOSEPHINE EKPERECHUKWU}

Dr Ukoh is a graduate of Banking and Finance, Nnamdi Azikiwe University, Awka Anambra State, Nigeria. She is a research fellow in Bursary Unit, Nnamdi Azikiwe University, Awka Anambra State, Nigeria. Her research interests include Economic Development and Financial Management.

(Phone: +2348033457270)

https://doi.org/10.37602/IJSSMR.2020.3406

\begin{abstract}
This study examined the relationship between Foreign exchange rate fluctuations and foreign direct investment (FDI) in Nigeria from 1981 to 2018. This study was motivated by conflicting results regarding how foreign exchange rate changes influenced foreign direct investment in varied economies especially in Nigeria, and to answer the question of whether Foreign Exchange rate fluctuations adversely retarded the flow of Foreign Direct Investment in Nigeria or otherwise. The study adopted an ex-post facto research design using annual time series data from the Central Bank of Nigeria (CBN) statistical bulletin. The model was estimated using the Vector Error Correction (VEC) model. The result of the analysis revealed that foreign direct investment has positive but no significant relationship with Foreign exchange rate fluctuations; and there was no granger causality existing between foreign exchange rate and foreign direct investment in Nigeria. The paper submits that foreign direct investment inflow could be attracted if stable foreign exchange regime is sustained and ease of doing business in Nigeria is satisfactory. The paper recommended among others that the Central Bank of Nigeria should sustain the foreign exchange rate policies especially by financing commercial farming and agro-allied businesses and encouraging the standardization of products for exports; available foreign currency should be allocated mainly to export-oriented businesses; fully standardized Free trade zones and industrial layout should be marked out across the nations and private sectors should be encouraged to power the zones and layouts; and all levels of governments say the local, state and federal should work towards entrenching true federalism.
\end{abstract}

\subsection{INTRODUCTION}

Every nations work towards providing improving security and living standard of the citizens. Good environment for investments in activities that will actualize these are continually devised. Nations agree to relate among themselves to allow each other access to their 


\section{International Journal of Social Sciences and Management Review}

endowments for the collective interests of humanity. The process through which economies, societies and culture relate through trade, transportation and communication is known as globalization. Promotion of foreign investment is one of such devices. Foreign investment (FI) is defined as overseas investment by private multinational corporations (Todaro \& Smith 2003). Foreign investment inflow, particularly foreign direct investment (FDI) is seen to have a positive impact on the economic growth of a host country through various direct and indirect means. Some foreign firms have taken advantage of the incentives to satisfy their various motives of ensuring stable monopolistic control over sources of raw materials for their parent companies, access to control of local markets, utilizing low-cost labour and realizing the possibility of higher returns which is important to every business organization because, with enough fund, an entrepreneur can get other factors of production such as labour, machinery or technology, management as well as raw materials and be involved in any other business activity (Okafor \& Arowshegbe, 2011).

Economists support the view that capital flow is beneficial because they create new resources for capital accumulation and encourage growth in developing economy with capital shortages. There is potential advantages of cross-border capital flows which economic theory pointed out to bridge the gap between investment and domestic saving that increases growth. In economies, capital flow plays a significant role.

World Bank (1996) conceptualized Foreign Direct Investment (FDI) as an investment that is made to acquire a lasting management interest (usually 10\% of voting stock) in an enterprise and operating in a country other than that of the investors, the investors purpose being an effective voice in the management of earning either long term capital or short term capital as shown in the nations balance of payments account statement (Macaulay, 2012). It is an investment made by a company or individual in another country, in the form of either establishing business operations or acquiring business assets in the other country, such as ownership or controlling interest in a foreign company. Foreign direct investment frequently involves more than just a capital investment. It may include the provision of management or technology as well. In fact, FDI is an agent that facilitates increased fund and transfer of technology which increases economic output.

Prior to the introduction of the Structural Adjustment Programme (SAP) in 1986, the Nigerian economy was dominated by the public sector. Thereafter, the private sector has been encouraged through policy changes and enactment of laws aimed at diversifying the economy via private sector participation. It is believed that the growing population of Nigeria and economic performance indicators can grow meaningfully if the government creates enabling environment for creativity, industry and technology transfers. Foreign investors' participation can definitely bridge the gap in the economy and the living standard of the populace (Moghalu, 2009).

Nigeria's foreign investment can be traced back to the colonial era when the colonial masters had the intention of exploiting the nation's resources for the development of their own economies. There was little investment by these colonial masters (Macaulay, 2012). The Nigerian governments have recognized the importance of FDI in enhancing economic growth and development and various strategies such as tax holidays for foreign and local investors and the signing of "ease of doing business" have been signed into law. Of course, since the 


\section{International Journal of Social Sciences and Management Review}

enthronement of democracy in 1999, the government of Nigeria has taken a number of measures necessary to persuade foreign investors into Nigeria. The measures noted, include the repeal of laws that are detrimental to foreign Investment growth, circulation of investment laws, various overseas trips for image laundry by the President among others (Shiro, 2009).

Privatization was also adopted, among other measures, to encourage foreign investments in Nigeria. This involved transfer of state-owned enterprises (manufacturing, agricultural production, public utility services such as telecommunication, transportation, electricity and water supply), companies that are completely or partly owned by or managed by private individuals or companies (Lall, 2002).

In addition, the various Foreign Exchange regimes of the Nigeria government were designed not only to achieve price stability but also to promote FDI inflows. This became evident from 1987 when the nation adopted flexible Foreign Exchange regime against the fixed exchange rate regime starting from 1960 to 1986. The Government has applied strategies such as Second-Tier Foreign Exchange Market (SFEM), Inter-bank Foreign Exchange Market (IFEM), Wholesale Dutch Auction System (wDAS), and Retail Dutch Auction System (rDAS) to address Foreign Exchange rate crisis.

Foreign direct investment (FDI) in Nigeria has not been relatively predictable, though it appreciated relatively between 1986 and 2018. However, the FDI inflow fell from 1360.3 billion in 2011 to $\$ 602.1$ in 2015. As of December 2016, it was $1,124.1$ billion (CBN, 2017). More so, the FDI in Nigeria seems shifting more and more towards services; these services are also becoming more traditional (Adeolu \& Simon, 2004). Balogun (2003) observed that very little foreign investment capital in Nigerian agricultural and agro-allied industries. The FDI in Nigeria increased from $\$ 2731$ billion to $\$ 75,9$ billion between 1994 and 1995 about $241.9 \%$ percentage increase; the agricultural and agro-allied sector share was merely $3.6 \%$ growth. While FDI fell by $18.4 \%$ in 2015 , the agricultural sector maintained a growth rate of $3.7 \%(\mathrm{CBN}, 2018)$.

FDI can stimulate additional resources to break the vicious circle of poverty and act as a complementary tool for domestic resources to raise the living standard of the citizens. FDI tries to bridge the capital shortage gap and complement domestic investment when it flows to high-risk areas of new firms where the domestic resource is limited. It is given, all things being equal investment determines the rate of accumulation of physical capital, and an important factor in the growth of productive capacity of any economy (Adeolu \& Simon, 2004).

Nigeria is plagued by lingering foreign perception of being a high-risk country for investment with a challenging business environment. The country still remains hobbled with the perception and image of being corrupt, having the inadequate infrastructure and recurring shortage of power and water supply in some parts of the country. Yet, one of the largest beneficiaries of foreign direct investment (FDI) in sub-Saharan Africa is Nigeria. Foreign Direct Investment has been the bedrock of many developed and developing economies. It has stimulated growth through job creation and improvement in macroeconomic variables (Okafor \& Arowshegbe, 2011). 


\section{International Journal of Social Sciences and Management Review}

The exchange rate which hitherto exhibited relative stability has tended volatile. For instance, between 1981 and 1985 the per \$ was averaged $\$ 0.73314$; between 1986 and 1991, the average was $\$ 6.0076$; between 1992 and 1997 it was $\$ 21.8861$; between 2000 and 2015 the exchange rate was average of 148 , and between 2015 and 2018 the exchange rate was averaged 250. The depreciation in naira is yet to be abet. It is pertinent therefore to evaluate the relationship between foreign direct investment and foreign exchange rate fluctuations in Nigeria. The paper aimed at examining the relationship existing between the Foreign exchange rate and Foreign Direct Investment in Nigeria (1981-2018) using data obtained from the Central Bank of Nigeria Statistical Bulletin, 2018; and proposed that: Foreign exchange rate fluctuations have no significant effect on Foreign direct investment in Nigeria.

The other sections of this paper include conceptual reviews; theoretical framework; empirical literature; methodology; data presentation and analysis; summary of findings; conclusion and recommendations.

\subsection{CONCEPTUAL REVIEW}

\subsection{Foreign Investment:}

Foreign Investment (FI) is a very important element in international economic integration. FDI creates direct, stable and long-lasting links between economies. Foreign Direct Investment encourages the transfer of technology and know-how between countries and allows the host economy to promote its products more widely in international markets. It is also an additional source of funding for investment and under the right policy environment; it can be an important vehicle for development (OECD Factbook, 2012). The term FDI also means the cross-border investment by a resident entity in one economy with the objective of obtaining a lasting interest in an enterprise resident in another economy.

FDI refers to investment by large multinational corporations with headquarters in the developed nations (Amadi, 2002). It is a distinctive feature of multinational enterprises. Thus, FDI is not simply an international transfer of capital but rather, the extension of enterprise from its home country (Tadaro, 1999). According to Root (1984), FDI involves flows of capital, technology and entrepreneurial skills to the host economy where they are combined with local factors in the production of goods for local and export markets. Mwilima (2003) describes FDI as investment made to acquire a lasting management interest (usually at least $10 \%$ of voting stock) and acquiring at least $10 \%$ of equity share in an enterprise operating in a country other than the home country of the investor. FDI has further been explained as the long-term investment reflecting a lasting interest and control, by a foreign direct investor (or parent enterprise), of an enterprise entity resident in an economy other than that of the foreign investor (IMF, 1999). Mallampally and Sauvant (1999) describe FDI as investment by multinational corporations in foreign countries in order to control assets and manage production activities in those countries.

Expanded explanation of the meaning of FDI has been offered by Ayanwale (2007). He explained that ownership of at least $10 \%$ of the ordinary shares of voting stock is the criterion for the existence of a direct investment relationship. FDI comprises not only merger and 


\section{International Journal of Social Sciences and Management Review}

acquisition and new investment, but also reinvested earnings and loans and similar capital transfer between parent companies and their affiliates (Ayanwale, 2007). Ikiara (2003) noted that foreign firm may allow local firms to appropriate its technology if this guarantees its access into some of the benefits available in the host country such as access to valuable local technology and possibility of receiving commercial advantages. By implication, developing countries like Nigeria requires such technical change and technological learning to achieve meaningful growth.

\subsection{International Trade and Foreign Direct Investment:}

Two important questions that an enterprise seeking to serve foreign markets must address are: First, is it better to produce the goods in the home country and export to foreign markets, or is production abroad more profitable? Secondly, is it for production abroad, how should technology be transferred overseas? Enterprises can choose from a variety of arrangements that differ in their relative use of markets and organizations. On one hand arrangement transfers technology to wholly-owned subsidiaries and on the other hand, transfers technology to unrelated parties through licensing. When serving a foreign market, an enterprise can choose from a number of options.

The literature mainly focuses on the choice between exports and FDI, assuming that exports and FDI are substitutes for one another. However, empirical work usually exposes a complementary relationship between exports and foreign affiliate sales. For instance, Lipsey and Weiss (1981) find that sales of foreign affiliates are positively correlated with exports. The industry level firm-level studies, such as Lipsey and Weiss (1984) and Blomstrom and Kokko (1998) also uncover a complementary relationship between trade and FDI. Does the evidence imply that most theoretical models are flawed? Only a study of the type done by Blonigen (1999) can really sort out the complementary nature of trade between intermediate goods and affiliate sales on the one hand and the substitutability of exports of final goods and FDI on the other. Not surprisingly, Blonigen's results agree nicely to the theory: exports of intermediate goods and sales of affiliates are complements, whereas exports and sales of final goods are substitutes. The only unresolved issue is why aggregate studies find a net complementary relationship. The explanation probably lies in the fact that most intraindustry trade between industrial countries involves the exchange of intermediate goods (Ethier, 1982).

The literature on intra-industry trade as derived from Dixit and Stiglitz's (1977) model may overemphasize the role of product differentiation and consumer emphasis on variety. As Ethier (1982) notes, actual trade is in intermediate goods needed for production. Thus, if such trade is indeed pervasive, there should be a strong complementary relationship between exports and FDI at the aggregate level. In other words, strategic considerations influence the choice between exports and FDI (Horstmann \& Markusen, 1992). The presence of trade barriers creates a tariff-jumping motive for FDI. The mere threat of future trade restrictions may lead to anticipatory investment by foreign firms. When two enterprises are exporting to a foreign market, a switch from exports to FDI by one creates an incentive for FDI on the part of the other firm, which finds itself at a competitive disadvantage (Lin \& Saggi, 1999). This is called a competitive incentive for FDI. 


\section{International Journal of Social Sciences and Management Review}

An old tradition in the management literature describes the interdependence between the decisions making of large multinationals as follow-the-leader behaviour. Hence, enterprises face a dynamic problem, just an onetime choice between exports and FDI. Enterprises may (and indeed do) switch between the two activities over time. Unfortunately, there is scarce literature that explores the dynamics of optimal entry strategies into foreign markets. Saggi (1998) builds a two-period model to investigate an enterprise's choice between exports and FDI in the face of demand uncertainty. Initial - period exports yield information about demand in the foreign market. As a result, initial-period exports have option value. That is, if a significant portion of the fixed cost of FDI is sunk, it is optimal for an enterprise to export in the initial period and to choose FDI if and only if demand abroad is large enough. Clearly, the preceding argument is not specific to demand uncertainty and can be generalized with respect to other types of uncertainty about which sales through exports can yield information. Roberts and Tybout (1997) highlight the role of sunk costs in determining the dynamic behaviour of exporters. Using data for Colombian manufacturing plants, Roberts and Tybout show that prior exporting experience is an important determinant of the current tendency to export as well as the profitability of exporting. Their results show that sunk costs are indeed relevant for export behaviour and that learning is subject to strong depreciation.

The entry costs of a plant that has never exported do not differ significantly from those of plants that have not exported to more than two years. Although Roberts and Tybout (1997) do not consider other modes of serving foreign markets, their insight can be utilized in a more general context. Suppose enterprises also have the option of FDI. Building on the Roberts and Tybout approach, the choice between exports and FDI is a choice between two different technologies, where exports entail a higher marginal cost and a lower fixed (sunk) cost than FDI (Saggi, 2002). Under uncertainty, if enterprises do face such a cost structure, an interesting dynamic relation between exports and FDI may emerge. Similarly, exports and initial FDI may be strongly complementary because enterprises are not likely to shift the entire production process to a new location immediately. If first investment is profitable, local sourcing may reduce the need for imported intermediates. Often, such substitution effects may become stronger, and the complementarities between exports and FDI may become weaker (assuming local suppliers are indeed competitive or local production is consistent with comparative advantage considerations). Also the presence of multiple enterprises also creates the possibility of information externalities among investors; that is, the experience of one enterprise may impart lessons to others.

Enterprises from industrialized countries have little prior experience in operating in these new environments. This lack of experience coupled with the complexity surrounding the FDI decision implies that enterprises seeking to invest in these markets can learn valuable lessons from the successes and failures of others. Such externalities may be particularly relevant for FDI in many developing and formerly closed economies (China and much of Eastern Europe). FDI involves hiring foreign labour, setting up a new plant, meeting foreign regulations, and developing new marketing plans; these decisions require adequate information. In this context, decisions made by rival enterprises can lower an enterprise's fixed cost by helping avoid mistakes. For instance, Lin and Saggi (1999) use a duopoly model in which the initial enterprise to switch from exporting to FDI confers a positive externality on the subsequent investor by lowering its fixed cost of FDI. In their survey of Japanese firms planning investments in Asia, Kinoshita and Mody (1997) find that both 


\section{International Journal of Social Sciences and Management Review}

private and public information play major roles in determining investment decisions. They argue $d$ that information regarding many operational conditions (such as the functioning of labour markets, literacy, the productivity of the labour force, and timely availability and quality of inputs) may not be available publicly. Such information is either gathered through direct experience or through the experience of others.

FDI is also a form of transferring production technology, skills, innovative capacity, and organizational and managerial practices between locations, and also of procuring international market networks (Mallampally \& Suavant, 1999). The main reasons for countries to seek investments by Multinational Corporations are to obtain modern technology and knowledge. The assumption is that new technology and knowledge could transfer to domestic enterprises which will improve their output (Blomstrom \& Kokko, 1998). These transfers and externalities can occur through various forms.

The transfer may occur when the well-trained staff of foreign enterprises' set up their own plants or become employed in locally-owned enterprises. The operation of Multinational Cooperation may lead to the dissemination of information on new technology and production methods also referred to as "the demonstration effect". By associating with domestic enterprises, foreign associates may improve the production competence of the host country (Rodriquez-Clare, 1996). There may be competition effect, where the emergent of foreign plants may accelerate competitions and so push domestic enterprises into being more effective and innovative (Doan, 2010). Another reason why governments make efforts to attract FDI is that it creates employment and FDI may generate foreign exchange for the host country if the Multinational Cooperation are export-oriented.

In sharp contrast to other forms of capital flows, FDI has proven to be resilient during the financial crisis (Prakash \& Assaf, 2001; Haussmann \& Fernandez- Arras, 2000; Dudash, 2000; Lipsey, 2001). The East Asian crisis of 1997-98, the Mexican crisis of 1994-95 and the Latin American debt crisis of the 1980s all attest to this. This is why Haussmann and Hernandez-Arias (2000) further indicate that many host countries regard international debt flows, mostly the short-term ones as "bad cholesterol" because it is based on interest rate differentials and exchange rate expectations and not on long term considerations. In summary, in the long run, the transfer of technology and know-how (indirect) by Multinational Cooperation to domestic enterprises may be of more importance than direct effects of FDI.

\subsection{Institutional Conditions for Attracting FDI}

Governments have the sole duty of providing an enabling environment for FDI. They need to provide conditions such as a stable political and economic environment, the rule of law and good infrastructure. An enlightened and technically skilled workforce, low wages, an open economy and stable currency are also necessary (UNCTAD, 1997). Majority of these conditions, which can be analyzed through the principle of macro institutional economies (North, 1991), develop gradually, take time to grow and are path-dependent, being enshrined in the institutional heritage of the host country. Only countries measuring up to the basic minimum standards on the said conditions suffice for more evaluation by multinationals. 


\section{International Journal of Social Sciences and Management Review}

The next stage of the drafting procedure is when enterprises use the micro or transaction cost view (Williamson, 1985), to consider issues such as project-specific incentives, tax breaks, restrictions on investment ceiling, majority control and profit repatriation, stipulations about local content, technological transfer and export requirements. It needs a comprehensive approval of all these features to arrive at a holistic picture of whether the potential FDI destination is investment friendly or not. It is obvious that these high standards are not likely to be met by any country solely. Developing countries cannot equivalently meet the same standards that developed countries have. Multinational Cooperation has a different combination of FDI factors for them. However, the necessity to lower costs would compel Multinational Corporation to trade off the standard combination in favour of low wage benefits. This is one of the essences of foreign exchange rate management.

The benefits of FDI are many. FDI develops enterprises directly and helps to strengthen economic potential. This is been achieved through two major forms: Greenfield Investment; and Mergers and Acquisition. Greenfield investment is adding new and different economic activity and thereby diversifying the economy while mergers and acquisition (M\&A) involves building up existing enterprises and enhancing their potentials. Both of these investments will add a new healthy element of increased competition to an economy since their products generally exhibit economies of scale and scope (Eichengreen \& Mussa, 1998). Foreign direct investment can boost the economy through competition. The entrance of foreign investors spurs other firms to increase their own efficiency and productivity. The competition also leads to the improved efficient allocation of resources, enhancing the economic prospect of the domestic economy and global sustainable economic development. Competitions also spur domestic competitors to build up their technological capabilities and the productivity of their products in the face of technology transfer and the development of human capital often associated with foreign direct investment. Therefore, the entry of foreign investors can make domestic producers more efficient by enhancing competitive pressure (Obstfeld, 1994).

Technology transfer and Human capital development are often assumed as the two primary benefits of FDI. Foreign investors bring their management skills and technology to their enterprise, so by training the local workforce, they transfer those skills and technology to them. When those workers move on to other jobs in the domestic enterprises or start their own businesses, they put to use the skills they have acquired. In this way, the human capital of the host country is developed by FDI and the investment technology transferred.

Foreign investment may lead to rapid monetary expansion and too much increase in domestic demand, which cause inflationary pressures and the appreciation of real deficits. Akeoraoglu (2000) showed that investment inflows may result in growth in domestic absorption. When some of the spendings fall on non-traded goods, their relative costs increase and real exchange rate rises. This boosts the demand for tradable goods, leading to current account deficits. However, if there is a fixed or crawling peg exchange rate regime, the central bank takes on either sterilized or non-sterilized policies to deal with exchange rate pressures due to investment flows (Berument \& Dincer, 2004). The sterilized intervention involves sales of government bonds by the central bank in exchange for foreign currencies and securities. For the effectiveness of this intervention, domestic and foreign bonds should be imperfect substitutes. Nevertheless, sterilized intervention makes interest rate differential between 


\section{International Journal of Social Sciences and Management Review}

home and foreign currency to enlarge, which attracts more investment flows. In a nonsterilized intervention, the central bank buys foreign currency in place of the domestic currency. This process compels the central bank to appreciate the nominal exchange rate, which leads to a fall in the interest rate differentials still. This policy also leads to an increase in the monetary base, which adds to inflationary pressures. Under a floating exchange rate regime, there is no central bank intervention. Thus, for a given level of shift in initial capital flows, the rise in the value of domestic currency and decline in domestic interest rates, and the constancy of investment inflows are inadequate relative to one under a fixed (or crawling) exchange rate.

Foreign direct investment may also improve the development of equity markets and the shareholders, corporate governance. As business organizations contest for finance the market will compensate for better performance, improved prospects for future performance and more excellent corporate governance (Berument \& Dincer, 2004).

\subsection{FDI and Multinational Corporations:}

Multinational Corporation subsidiaries in some countries can play a major role in establishing building blocks of organizations. Westney (1993) discusses the potentially significant impacts of Multinational Corporation on the organizational patterns within a country. The introduction of new modes of business practice in Multinational Corporation subsidiaries can challenge the legitimacy of existing patterns and stimulate debates on better business practice in the host country. The mirror image of this influence is the 'de-institutionalization' of local firms' existing organizational patterns. Similarly, Dacin, Ventresca and Beal (1999) discussed the concept of 'disembeddedness'. They argue that globalization may be regarded as a disembedding process that strips individuals and firms from their local structures and allows for restructuring at a more global level. Following this perspective, it is likely that the presence of foreign-owned subsidiaries will, on average, reduce the level of corruption of the host country. The Multinational Corporation influences its institutional environment overtime via three major effects: regulatory pressure effect, demonstration effect, and professionalization effect. One motivating factor for the host institutions to change is that the host country also wants to gain legitimacy within the bigger, global business environment. As the host country grows, it would like to enhance its international reputation and attract more business (Kostova \& Roth, 2002; Oliver, 1997; Don, 2003; Aitken \& Harrison, 1999; Liu, 2000; Robertson \& Watson, 2004; Eden, 1997; DiMaggio \& Powell, 1983; Ramirez \& Kwok, 2006).

\subsection{FDI and the Nigeria government:}

When the democratic government took over in May 1999, it declared its interest to attract and welcome FDI into the country as the opportunities emanating from FDI injection into an economy is sustainable (Adeseyoju, 2001). Nigeria government has been making efforts to enhance FDI inflows through various reforms. The reforms include the deregulation of the economy, gazette of the industrial policy of 1989, the establishment of the Nigeria investment promotion commission (NIPC) in the beginning of the 1990s and the signing of the Bilateral Investment Treaties (BIT) in the latter part of the 1990s. Further reforms were the establishment of the economic and financial crime commission (EFCC) and the Independent 


\section{International Journal of Social Sciences and Management Review}

Corrupt Practices Commission (ICPC). Nevertheless, FDI inflows to Nigeria have remained far below sufficient (Nurudeen, 2010). In 2006, the Central Bank of Nigeria reported a surge in FDI inflows to the country. This was traceable to the reduction in the nation's debt profile through debt arrangements with London club and Paris Club and the renewed confidence of foreign investors in the Nigerian economy (CBN, 2006).

Aremu (2003) related some Nigerian government policies that influenced the direction of FDI. These are depicted in Table 1.

Table 1 Outline of FDI Policies in Nigeria

\begin{tabular}{|c|c|c|c|c|}
\hline Year & Law/policy & Motive & Aim & Comments \\
\hline 1958 & $\begin{array}{l}\text { Pre- } \\
\text { independence } \\
\text { era: }\end{array}$ & $\begin{array}{l}\text { Industrial } \\
\text { Tax relief }\end{array}$ & $\begin{array}{l}\text { To grant a maximum of } 5 \\
\text { year tax holiday from } \\
\text { inception date, to foreign } \\
\text { companies operating in } \\
\text { Nigeria }\end{array}$ & $\begin{array}{l}\text { This was a strategy to } \\
\text { attract Trans National } \\
\text { Corporations (TNCs) by } \\
\text { offering generous } \\
\text { incentives. }\end{array}$ \\
\hline 1972 & $\begin{array}{l}\text { Indigenization } \\
\text { Era: Nigerian } \\
\text { Enterprise } \\
\text { Promotion Act } \\
\text { (NEP) }\end{array}$ & $\begin{array}{l}\text { Restrictive } \\
\text { measure }\end{array}$ & $\begin{array}{l}\text { To restrict FDI in } \\
\text { enterprises. These } \\
\text { schedules were put in } \\
\text { place: Schedule } 1 \text { requires } \\
100 \% \text { ownership of } \\
\text { enterprises by Nigerians } \\
\text { while schedule II requires } \\
\text { as much as } 40 \% \\
\text { ownership by foreigners. }\end{array}$ & $\begin{array}{l}\text { Foreign investors were } \\
\text { not adequately } \\
\text { compensated for } \\
\text { disposition of assets. } \\
\text { Thus the } \\
\text { implementation } \\
\text { violated international } \\
\text { investment laws. }\end{array}$ \\
\hline 1977 & $\begin{array}{l}\text { Nigerian } \\
\text { Enterprise } \\
\text { Promotion Act } \\
\text { (NEP) }\end{array}$ & $\begin{array}{l}\text { Restrictive } \\
\text { measure }\end{array}$ & $\begin{array}{l}\text { An amendment of NEP } \\
\text { Act, } 1972 \text {, which resulted } \\
\text { in lowering the maximum } \\
\text { limit of foreign ownership } \\
\text { from } 60 \% \text { to } 40 \% \text {, and } \\
\text { expansion of business } \\
\text { activities under } \\
\text { restriction. }\end{array}$ & $\begin{array}{l}\text { Indigenization of major } \\
\text { enterprises in Nigeria }\end{array}$ \\
\hline 1987 & $\begin{array}{l}\text { Nigerian } \\
\text { Enterprise } \\
\text { Promotion Act } \\
\text { (NEP) }\end{array}$ & $\begin{array}{l}\text { Promotion } \\
\text { strategy }\end{array}$ & $\begin{array}{l}\text { An amendment of the } \\
\text { NEP Act 1977, to provide } \\
\text { an opportunity for foreign } \\
\text { investors to increase } \\
\text { investment without } \\
\text { increasing their voting } \\
\text { power }\end{array}$ & $\begin{array}{l}\text { Due to the emergence } \\
\text { of a separate body to } \\
\text { monitor the } \\
\text { compliance of the Act, } \\
\text { it resulted in the } \\
\text { development of "red } \\
\text { tape" to foreign }\end{array}$ \\
\hline
\end{tabular}




\section{International Journal of Social Sciences and Management Review}

Volume: 03, Issue: 04 "July - August 2020"

ISSN 2582-0176

\begin{tabular}{|c|c|c|c|c|}
\hline & & & & investors in Nigeria. \\
\hline 1988 & $\begin{array}{l}\text { Industrial } \\
\text { Development } \\
\text { Coordinating } \\
\text { Committee } \\
\text { (IDCC) Act }\end{array}$ & $\begin{array}{l}\text { Promotion } \\
\text { strategy }\end{array}$ & $\begin{array}{l}\text { IDCC was to act as a one- } \\
\text { stop agency to approve } \\
\text { and regulate investment } \\
\text { in Nigeria (as } \\
\text { recommended by The } \\
\text { World Bank). To } \\
\text { streamline the investment } \\
\text { procedure by shrinking } \\
\text { similar government } \\
\text { departments into one. }\end{array}$ & $\begin{array}{l}\text { The agency } \\
\text { underperformed due } \\
\text { to dishonest practises, } \\
\text { as enterprises gave } \\
\text { false information to } \\
\text { secure expatriate } \\
\text { quotas. }\end{array}$ \\
\hline 1989 & $\begin{array}{l}\text { Nigerian } \\
\text { Enterprise } \\
\text { Promotion Act } \\
\text { (NEP) }\end{array}$ & $\begin{array}{l}\text { Promotion } \\
\text { strategy }\end{array}$ & $\begin{array}{l}\text { To eliminate the } \\
\text { discriminatory approach } \\
\text { towards foreign investors } \\
\text { that existed in previous } \\
\text { NEP acts. Schedule I and II } \\
\text { were abolished, and } \\
\text { Schedule III was amended } \\
\text { to allow ownership of } \\
\text { enterprises with more } \\
\text { than } 20 \text { million naira } \\
\text { capitalization. }\end{array}$ & $\begin{array}{l}\text { A turn around } \\
\text { amendment to open } \\
\text { up to FDI }\end{array}$ \\
\hline 1990 & $\begin{array}{l}\text { Companies and } \\
\text { Allied Matters } \\
\text { (CAMA) }\end{array}$ & $\begin{array}{l}\text { Promotion } \\
\text { strategy }\end{array}$ & $\begin{array}{l}\text { To mandate foreign } \\
\text { companies incorporate } \\
\text { outside Nigeria to } \\
\text { incorporate in Nigeria. } \\
\text { Failure to incorporate will } \\
\text { lead to termination of the } \\
\text { right to operate in the } \\
\text { country. }\end{array}$ & $\begin{array}{l}\text { The law was basically a } \\
\text { measure to ensure the } \\
\text { documentation and } \\
\text { monitoring of the } \\
\text { activities of foreign } \\
\text { firms by government } \\
\text { authorities. }\end{array}$ \\
\hline 1995 & $\begin{array}{l}\text { Nigerian } \\
\text { Investment } \\
\text { Promotion } \\
\text { Commission } \\
\text { (NIPC) Act 16, } \\
1995\end{array}$ & $\begin{array}{l}\text { Promotion } \\
\text { strategy }\end{array}$ & $\begin{array}{l}\text { To promote and direct } \\
\text { investment in Nigeria. } \\
\text { Also, to market the } \\
\text { Nigerian investment } \\
\text { environment to potential } \\
\text { foreign investors }\end{array}$ & $\begin{array}{lr}\text { A more radical } \\
\text { approach } \\
\text { previous IDDC } \\
\text { (Aremu, 2003) }\end{array}$ \\
\hline 1995 & $\begin{array}{l}\text { Foreign Exchange } \\
\text { Monitoring and } \\
\text { Miscellaneous }\end{array}$ & $\begin{array}{l}\text { Liberalization } \\
\text { To liberalize } \\
\text { foreign }\end{array}$ & $\begin{array}{l}\text { This was an amendment } \\
\text { of the Exchange Control } \\
\text { Act, } 1962\end{array}$ & $\begin{array}{lr}\text { Liberalization } & \text { To } \\
\text { deregulate } & \text { the } \\
\text { Nigerian } & \text { Capital }\end{array}$ \\
\hline
\end{tabular}




\section{International Journal of Social Sciences and Management Review}

Volume: 03, Issue: 04 "July - August 2020"

ISSN 2582-0176

\begin{tabular}{|l|l|l|l|}
\hline $\begin{array}{l}\text { Provisions } \\
\text { (FEMAMP) Act }\end{array}$ & $\begin{array}{l}\text { exchange } \\
\text { transactions. }\end{array}$ & $\begin{array}{l}1999 \text { Investment and } \\
\text { Securities Act }\end{array}$ & $\begin{array}{l}\text { market, in order to } \\
\text { attract FDI } \\
\text { The enforcement of } \\
\text { the act required the } \\
\text { amendment of other } \\
\text { acts, to avoid the } \\
\text { conflict of objectives }\end{array}$ \\
\hline
\end{tabular}

Source: Adapted from Aremu (2003)

\subsection{Foreign Exchange Rate:}

The term "exchange rate" can be defined as the price of one country's currency in terms of another. lyoha and Unugbro (2005) defined exchange rate as the domestic price of a unit of foreign currency. It refers to the cost of exchanging one country's currency for others. Exchange rates are expressed in various ways:

- Spot Exchange Rate - the spot rate is the rate for a currency at today's market prices.

- Forward Exchange Rate - a forward rate involves the delivery of currency at a specified time in the future at an agreed rate. Companies wanting to reduce risks from exchange rate volatility can buy their currency 'forward' on the market.

- Bi-lateral Exchange Rate - the rate at which one currency can be traded against another. Examples include $\$$, \$/DM, Sterling/US Dollar, \$/YEN or Sterling/Euro.

- Effective Exchange Rate Index (EER) - a weighted index of sterling's value against a basket of currencies the weights are based on the importance of trade between say Nigeria and each country.

- Real Exchange Rate - this is the ratio of domestic price indices between the two countries. A rise in the real exchange rate implies a worsening of competitiveness for a country.

In many developing countries exchange rate issues have tended to influence macroeconomic policy discussions. This is attributed to the amount of the effect which exchange rate has on decisions to save and invest as well as its being a major determinant of capital inflow and external competitiveness of a country. In pursuing some economic goals such as the achievement of a balance of payment viability, the maintenance of internal payment, as well as the solutions to the problems of defining, measuring, detecting and correcting situations of real exchange rate misalignment and overvaluation, the exchange rate management is a must. The exchange rate can also be employed to entice new investors. Exchange Rate Adjustment (ERA) has been undertaken by governments for a number of years (Obaseki, 1991).

When payments for transactions in a foreign currency are to be made, or received, the rate at which the two currencies change hands will be determined in the foreign exchange. Hence the market price is determined by supply and demand of foreign exchange. The exchange rate is a veritable instrument of economic management and the important macro-economic indicator used to assess the general performance of an economy (Ojo, 2003). 


\section{International Journal of Social Sciences and Management Review}

Exchange rates are important yardsticks for measuring economic performance, particularly, the impact on price signals, international trade and foreign direct investment. Exchange rate regimes in Nigeria have gone through different levels of changes. Aizenman (1992) shows that a fixed exchange rate regime is more convenient for FDI than a flexible exchange rate, not minding the type of shock hitting an economy. When there is monetary shock, the nominal shocks reduce expected profits from under a flexible exchange rates regime. For real shocks, flexible exchange rates are linked with higher employment volatility and lower expected returns. This arises because a country having a positive productivity shock usually experiences nominal and real appreciation which reduces the effect of employment expansion. For fixed exchange rates, the level of employment and production can be isolated from monetary shocks, and they are related to higher expected returns. These, in turn, activate domestic investment and FDI. For real shocks under a fixed exchange rate, a positive productivity shock tends to expand employment and expected returns. So, in the face of productivity shocks, FDI flows will be more under a fixed than under a flexible exchange rate system.

The relationship between foreign investment and exchange rate has drawn attention from many studies. From the theoretical point of view, Phillips and Fredoun (2008) argue that the linkage between exchange rate risks and FDI can be classified into two major issues consisting of production flexibility and risk aversion. In the production flexibility approach, manufacturers commit to domestic foreign capacity ex-ante and to employment decisions expost, after the realization of real stocks. Thus, the movements of the exchange rate play no role in explaining the level of FDI. This argument is based on the assumption that firms can adjust their variable factors after the realization of exchange rate stocks, as a result, it would not be held if factors were fixed. With the risk aversion approach, the evidence could be grouped into two aspects. The first impact is derived from exchange rate steadiness. Stability of dollar matched with a rise in the level of total investment inflow suggests that international investments would be driven partly by the variability of the exchange rate.

Relatedly, the study of Foad (2005) shows that under the condition of limited potential direct investment, FD1 flows from the countries with a high level of exchange rate risk into the countries with higher stability in currency. This finding is consistent with Dixit and Pindyck (1994) who shows that FDI in a country with a high level of currency risk provides an uncertain flow of expected return on investment. As a result, the link between FDI and exchange rate stability is positive. Another effect can be obtained through the marginal revenue and cost channels. That is, it focuses on the effect of exchange rate differentiating investment decision based on the loss and profit from the investment. As suggested by Goldberg and Karlstad (1995) higher volatility in the exchange rate reduces the expected returns functions of firms that make investment decisions in the current period in order to realize profits in future periods. According to Campa (1993), risk-neutral firms tend to postpone their decision to enter the foreign market in order to avoid high exchange rate variability. And, for Nucci and Pozzoco (2001) currency depreciation stimulates aggregate investment responses for Italian manufacturing firms through revenue channels and disincentive investment through cost channel. As long as FDI is somewhat irreversible, there is some positive value to holding off on this investment to acquire more information. Given that there is a finite number of potential direct investments, countries with a high degree of currency risk will lose out to countries with more stable currencies (Foad, 2005). 


\section{International Journal of Social Sciences and Management Review}

Exchange rate movement and exchange rate uncertainty seem to be important factors investors taken into consideration in the decision to invest abroad by investors. Foreign capital inflows are generally perceived as something desirable to the industrialized and developing countries. It can eliminate foreign exchange shortages, improve the standard of living, deepen and broaden the financial markets. Capital inflows have also helped individual countries to absorb shocks either internal such as harvest failures to external such as fluctuations in commodity price or recessions in industrial economies (Unugbro, 2007). Since the world has moved towards higher integration, a degree of openness for foreign investments in many countries becomes higher. As both developed and emerging economies continue to open their markets to attract foreign capital flows and investors are becoming more interesting in diversifying their fund flows internationally, the role of foreign investment is increasing in importance. Considering the major determinants of foreign direct investment, exchange rate risk is possibly seen as the most important determinant of foreign investment flows (Aranyarat, 2010).

\subsection{THEORETICAL REVIEW}

Vintila (2010) in the study of Foreign Direct Investment theories reveal that there is no unified theoretical explanation. It seems very unlikely that such a unified theory will emerge. However, a number of FDI related theories guided the thought in this work. Among the theories are:

New Growth Theory: A central proposition of New Growth theory as propounded by Solow (1987) is that, unlike land and capital, knowledge is not subject to diminishing returns. Indeed, the development of knowledge is seen as a key driver of economic development. The implication is that, in order to develop, economies should move away from an exclusive reliance on physical resources to expanding their knowledge base, and support the institutions that can help develop and share knowledge. Governments should invest in knowledge because individuals and firms do not necessarily have private incentives to do so. For example, while knowledge is a merit good, and acquiring it does not deny anyone else that knowledge, its usefulness to individuals and firms may be undervalued, and yet knowledge can generate increasing returns and drive economic growth. The government should, therefore, invest in human capital, and the development of education and skills. It should also support private-sector research and development and encourage local investment and foreign investment.

This theory equally emphasized that essential utilities like electricity, gas, and water are natural monopolies, and in many countries are provided by the public sector. However, if these utilities are under-supplied due to inadequate public funds, the private sector will suffer and growth will be limited. This is because the industrial sector relies on energy and water for its production and distribution, without which it will not produce efficiently or competitively. The accumulation of private capital, therefore, depends up the correct level of expenditure by the government. New Growth theorists also argue that the government should also finance, or seek finance for, infrastructure projects, such as road, rail, sea, and air transport. Such projects involve the creation of quasi-public goods, and the theory of market failure suggests that they would be 'under-supplied' without government. The huge fixed costs and the difficulty of charging users prevents the private sector supplying, and the state may choose to 


\section{International Journal of Social Sciences and Management Review}

act like a producer and financier, and provide necessary legislation for and co-ordination of such projects. These projects also generate positive externalities, and as such justify government involvement. For example, an improved infrastructure increases the likelihood of tourist revenue as well as reducing production costs.

The Theory of Exchange Rates on Imperfect Capital Markets: This is another theory which tried to explain FDI in relation to international trade. Foreign exchange risk as a determinant factor in international trade. Cushman (1985) showed that the foreign exchange rate has an influential effect on FDI. Cushman shows that real exchange rate increase stimulated FDI made by USD, while a foreign currency appreciation has reduced American FDI. Cushman concludes that the dollar appreciation has led to a reduction in United States FDI by $25 \%$. However, the currency risk rate theory has not convincingly explained simultaneous foreign direct investment between countries with different currencies. Thus, investments are made in different times, but there are enough cases that contradict these claims. This implies that foreign direct investment involves investing in a new enterprise by a parent company in a foreign country in order to maximize profit through the control and expansion of its market of that enterprise. This involves both ownership and control which distinguished it from international portfolio management.

This study is anchored on the Theory of Exchange Rates on Imperfect Capital Markets. The work proposes that economies that manifest growing potentials say in minimal costs of doing business, especially relatively stable foreign exchange rate and relative security will usually attract more foreign direct investment. Such potentials can hardly be observed in rising cost of doing business and insecure business environment. Thus, if the necessary structures are put in place, investors will be encouraged to invest given the promising and sustainable Foreign Exchange rate.

Capital Movement Theory: Capital movement theory is another related theory that opinioned that FDI is promoted transfer of knowledge. According Hymer (1960) following FDI in the industrial organization tradition, FDI is a way of shifting knowledge and other firm assets both tangible and intangible. This shifting does not include the transfer of ownership or control being renounced like in portfolio investment. His study showed that the idea of FDI as a single capital movement reacting to rates of return (with or without risk) did not correspond to the real characteristics of multinational's activities. He also pointed out that it was difficult to relocate their assets because of market imperfections. Imperfections is the concept of transaction costs. Transaction costs come from the difficulties of using the market to arrange transactions. Thus, the capital movement theory is connected with this study in the sense that in Nigeria there is no "ease of doing business". This can be attributed to transaction cost emanating from bribery and corruption associated to doing business in Nigeria.

\subsection{EMPIRICAL REVIEW OF RELATED LITERATURE}

A number of related empirical studies were reviewed. Bekarert and Harvey (2003) showed through an empirical study on 95 countries, that Capital Market Liberalization offers the opportunity to the foreign investors of investing in the domestic equities. This situation emerges with an increase with the order in $1 \%$ in growth rate. Omankhanlen (2011) in his study of the effect of Foreign Direct Investment on the Nigerian economy over the period 


\section{International Journal of Social Sciences and Management Review}

1980 -2009 examined empirically the effect of FDI on Balance of Payment, Inflation, Exchange Rate and Gross Domestic Product. The study developed an Economic model to investigate the relationships between the aforementioned variables and showed that Foreign Direct Investment has significant effects on the variables. He suggested that policymakers and relevant authorities should formulate policies aimed at creating a conducive investment environment so that Nigeria can be a better destination for foreign investment.

Adigwe, Ezeagba and Ude(2015), examining the effect of Foreign Direct Investment on Nigerian Economic Growth: 2008-2013 showed that a significant relationship exists between FDI, Exchange rate and GDP in Nigeria. This signifies that the duo of the Exchange rate and FDI affect economic growth significantly. While, Ugwuegbe and Okore (2013) examining the impact of Foreign Direct Investment on the Nigerian economy: 1981-2009, indicated that Foreign Direct Investment has a positive and insignificant impact on the growth of Nigeria economy and domestic investment economic growth while exchange rate had positively significantly effected on the growth of Nigerian economy.

In a study by Hongxin, Kim and Du (2003) on the impact of corruption and transparency on FDI based on a cross-country data of 40 countries in 7 years, they found that the presence of high corruption and low transparency significantly hindered the inflow of FDI to host countries. Multinational firms arrive with exporting information such as fixed costs to establish distribution networks, creating transport infrastructure, regulatory arrangements, learn about consumers' tastes and so on in overseas markets and so make use of these from the new host country. Therefore, through collaboration and more likely imitation, local firms can learn how to enter export markets.

Konings (2001) examined the effects of FDI on domestic firms: Evidence from firm-level panel data in emerging economies. Three (3) emerging economies of Central and Eastern Europe (Bulgaria, Romania and Poland) were used for the study. Using unique Firm-level panel data, estimation technique and Moment technique he showed that FDI maintained Negative effects and foreign firms reduce the productivity of local firms through competitive effects. In the long run, the work concluded that the technological spillover effects will start to dominate, leading to positive spillovers. Thus, foreign firms reduce the productivity of local firms through competition effects. This is because the multinationals have lower marginal costs due to some firm-specific advantages which allow them to pull demand away from domestic firms, thereby forcing them to reduce production.

Kokko (1996) studied Productivity spillovers from competition between local firms and foreign affiliates: Mexico evidence and showed that there is evidence for productivity spillover to domestic firms with moderate technology gaps, but not for firms that use considerable lower levels of technology. Thus, there is a positive effect of competition on domestic firms for Mexico. However, the spillovers depend on the complexity of the technology transferred by multinationals and on the technology distance between domestic firms and multinational firms. Using a cross-section industry-level data for Mexico, he finds no evidence for spillovers in industries in which multinationals use highly complex technologies (as proxied by large payments on patent or high capital intensity). Domestic firms can benefits only if the technology gap is not hidden so that domestic firms can assimilate the knowledge available from the multinational. Thus, there is evidence for 


\section{International Journal of Social Sciences and Management Review}

productivity spillovers to domestic firms with moderate technology gaps (measured as the difference between the domestic firm's labour productivity and the average labour productivity in foreign firms) but not for firms that use considerably lower levels of technology.

The result of empirical research conducted by Goldberg and Kolstad (1995) showed that increased exchange rate uncertainty has a positive impact on FDI. They used quarterly data to analyse bilateral investment flows between the United States (US) and the United Kingdom (UK), Canada, Japan between 1978 and 1991. They found out that exchange rate variability had a positive and statistically significant impact on four of the six bilateral FDI shares, and so real exchange rate variability increased the share of total U.S investment capacity located in Canada and Japan and increased the share of Canadian and UK investment situated in the United States. Exchange rate variability was insignificant only in a situation where problems arose in estimating the regression equations.

Servein (2003) using a GARCH model of volatility investigates exchange rate volatility and investment in developing countries and finds that exchange rate uncertainties negatively affect investment in developing countries. The study equally shows that financial systems and the degree of openness of a country are important in establishing the investment effect of exchange rate uncertainty. The work also shows that a more efficient financial system is positively related to investment.

Eun and Resnick (1988) investigated the effect of exchange rate volatility on the risk of foreign stock market investment and show that with the modern portfolio theory (MPT) investors estimate the risk-return nature of financial assets when considering optimal portfolio. In such a situation, exchange rate volatility leads to portfolio risk. On the other hand, based on an efficient international portfolio strategy, the volatility of the exchange rate is rather essential to multinational investors because of its ability to get potential gains from international diversification. They further examined that variability of the exchange rate and showed that it accounts for nearly fifty per cent of the variability of dollar returns from equity investment in such major countries as Japan, Germany and the United Kingdom.

Corsetti and Konstantinonu (2009) show that the valuation effect of exchange rate volatility acts as fund transfer across countries, with the capital gains to U.S investors following depreciation in dollar balanced by capital losses for foreign investors. This shows that the welfare consequences of the redistribution of wealth is actually considerable. Similarly, Gazioghi (2008) in a study of the effect of capital inflows and outflows on real exchange rates and the real stock market returns before and after the financial crisis in Turkey, finds an asymmetric impact of capital on exchange rate and stock market returns. In the case of Foreign Portfolio Investment, Bigger (1979) shows that from an international point of view, the overall rate of return from holding foreign financial assets consists of investment returns (dividends and capital gains) on the asset including gains and losses from the movement in the exchange rate at the holding period. The volatility of the exchange rate is an added source of uncertainty that may create both potential gains and losses to investors across countries. This also shows that the volatility of exchange rate quickly increases foreign investment risk in holding bonds and stocks, however the effect of exchange rate for volatility on 


\section{International Journal of Social Sciences and Management Review}

international investment is significantly more than investment risk for stock because stocks are more volatile when compared to bonds.

Esheneke and Oriavwote (2012) in their study of FDI and real effective exchange rate, market size and openness found that a depreciation of the real effective exchange rate will definitely attract more FDI to Nigeria. A weaker exchange rate might be expected to enhance FDI flows as a foreign firm makes use of the conveniences of low prices in host countries to acquire facilities. In a related study, Blonigen (2005) used a firm-specific asset study to show that exchange rate depreciation in host country leads to more FDI inflows. But Froot and Stein (1991) had hitherto asserted that a weaker host country currency favours increase in FDI inflows within an imperfect capital market setting because depreciation devalues host country assets if compares to that of the home country.

Athukorala and Rajapatirana (2003) studied Capital Inflows and the Real Exchange Rate: A Comparative Study of Asia and Latin America and showed that the degree of appreciation in exchange rate associated with foreign investments is much higher in some countries than in others. However, Asogwa, Okeke and Urama (2013) find no significant relationship between foreign capital inflows and exchange rate dynamics.

The gap in the literature which this study attempts to satisfy is whether Foreign Direct Investment is granger caused by foreign exchange fluctuations in Nigeria or otherwise.

\subsection{METHODOLOGY}

Using an ex-post facto research design which is the type of research involving events that have already taken place and for which data already exists, this paper aim at determining the cause-effect relationship between the foreign direct investment and Foreign Exchange rate in Nigeria from 1981-2018. The data used for the study are secondary data and were sourced from the Central Bank of Nigeria (CBN) Statistical bulletin of 2018 and the National Bureau of Statistics. Annual time-series data of the variables are used and they include total inflows for foreign direct investment and Foreign Exchange rate.

Vector Error Correction (VEC) model was used against Vector Autoregression model because of the non-stationarity of the variables. The AR roots graph indicated a modulus lying outside the unit circle. This was applied to examine the relationship between foreign exchange rate and foreign direct investment in Nigeria. This study adopted the VEC model of the form (Amisano \& Carlo, 1997):

$\Delta y t=A 1 y t-1+\ldots$ Ap yt-p + Bxt + Et

Where, $\mathrm{yt}=$ vector of endogenous variables, $\mathrm{xt}=\mathrm{d}$ vector of exogenous variables, $\mathrm{A} 1 \ldots, \mathrm{Ap}$ and $\mathrm{B}$ are matrices of coefficients to be estimated, and $\mathrm{Et}=$ vector of innovations that may be contemporaneously correlated but are uncorrelated with their own lagged values and uncorrelated with all of the right-hand side variables. Thus, this study stipulates that:

$\Delta \mathrm{EXRt}=$ a11EXRt-1 + a12FDIt-1 + b11EXRt-2 + b12FDIt $-2+\mathrm{c} 1+\mathrm{E} 1 \mathrm{t}$ 


\section{International Journal of Social Sciences and Management Review}

$\Delta$ FDIt $=$ a21EXRt-1 + a22FDIt-1 + b21EXRt-2 + b22FDIt $-2+\mathrm{c} 2+$ E2t

Where:

aij, bij, ci $=$ Parameters to be estimated and Et $=$ innovations FDI $=$ Foreign Direct Investment, and EXR = Foreign Exchange Rate.

Vector Autoregression (VAR) and Vector Error Correction Models were employed to estimate the co-integration relationship between Foreign Direct Investment and Foreign Exchange rate fluctuations. To ascertain the stationarity of the variables unit root tests were conducted using the AR Roots table. Residual tests and Normality tests were conducted and Granger causality was applied to determine the effect foreign exchange rate fluctuations on foreign direct investments in Nigeria. This was used to test the hypotheses formulated. The interest in this work is to establish the direction of causality between the variables of the model if any and thus the exact effect of the independent variables on the dependent variables and vice versa. The hypotheses were tested at $5 \%$ level of significance.

\subsection{Data Presentation and Analysis}

The input data processed in this work are shown in Appendix I, and the descriptive statistics are displayed in Table 2, Figures 1, 2, and 3.

Table 3: Descriptive Statistics of the input data

$\begin{array}{lll}\text { Mean } & \text { EXR } & \text { FDI } \\ \text { Median } & 88.66394 & 374.5306 \\ \text { Maximum } & 97.39930 & 113.6215 \\ \text { Minimum } & 306.0802 & 1360.308 \\ \text { Std. Dev. } & 0.610000 & 0.264300 \\ \text { Skewness } & 87.19147 & 442.7205 \\ \text { Kurtosis } & 2.799137 & 0.838227 \\ & & 2.215766 \\ \text { Jarque - Bera } & 4.046622 & 5.423738 \\ \text { Probability } & 0.132217 & 0.066413 \\ & & \\ \text { Sum } & 3369.230 & 14232.16 \\ \text { Sum Sq. Dev. } & 281287.1 & 7252052 . \\ & & \\ \text { Observations } & 38 & 38\end{array}$

Source: E-View output data, 2019 


\section{International Journal of Social Sciences and Management Review}

FDI

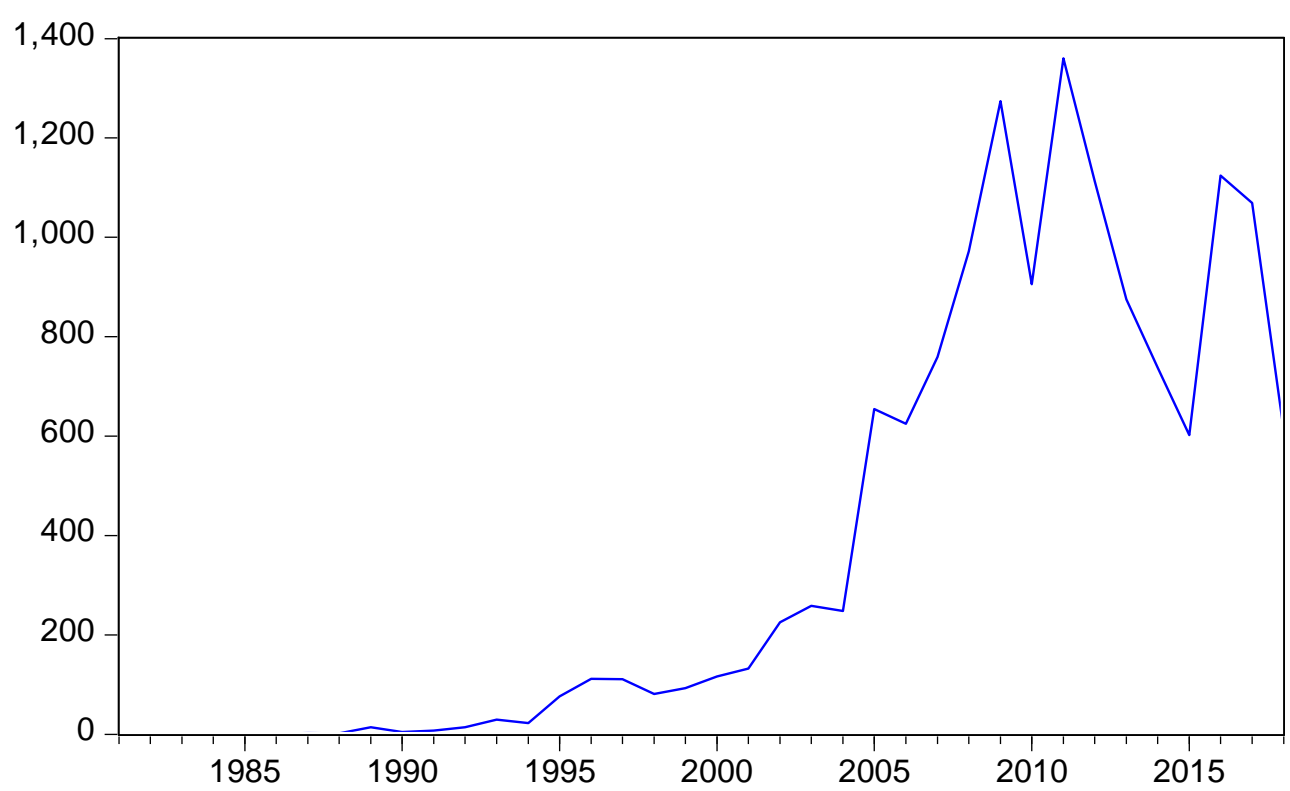

Source: E-View output data, 2019

Figure 1: Graphic representation of the FDI trend in Nigeria: 1981-2018 EXR

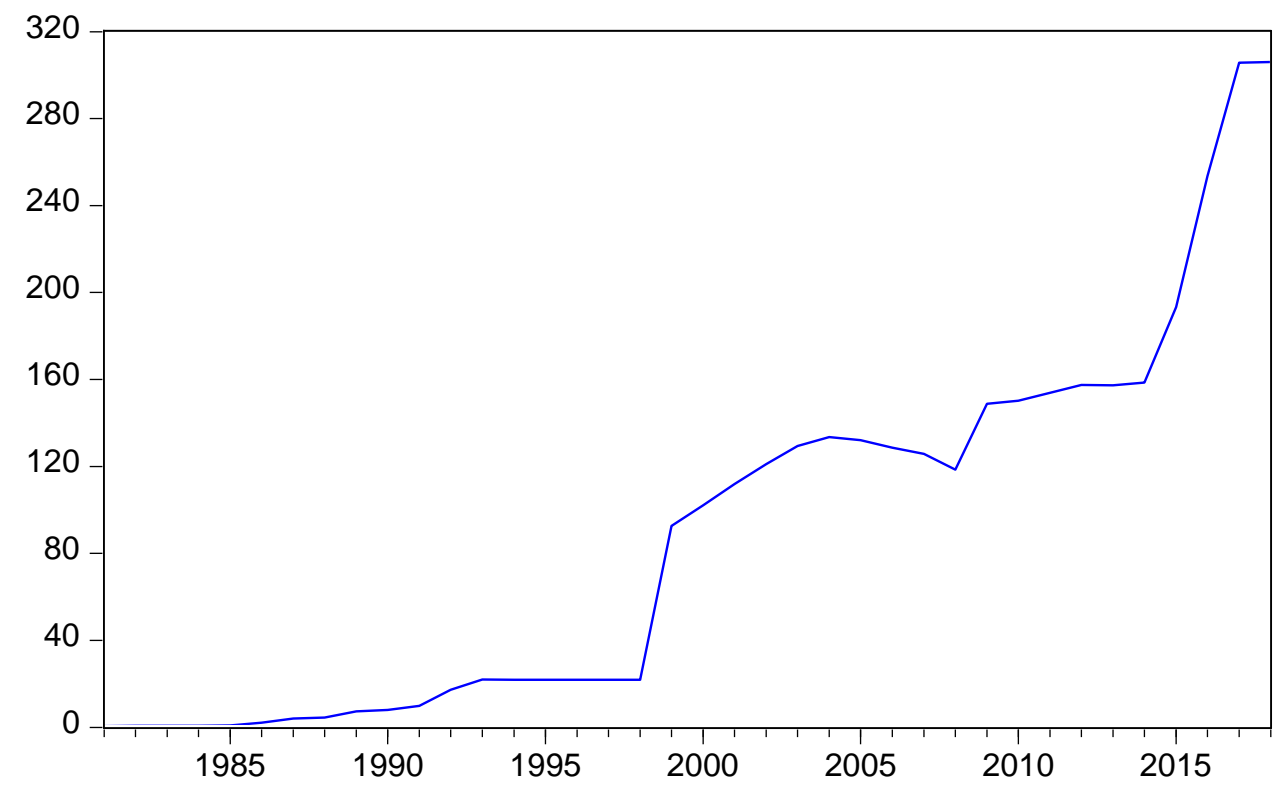

Source: E-View output data, 2019

Figure 2: Graphic representation of the EXR trend in Nigeria: 1981-2018 


\section{International Journal of Social Sciences and Management Review}

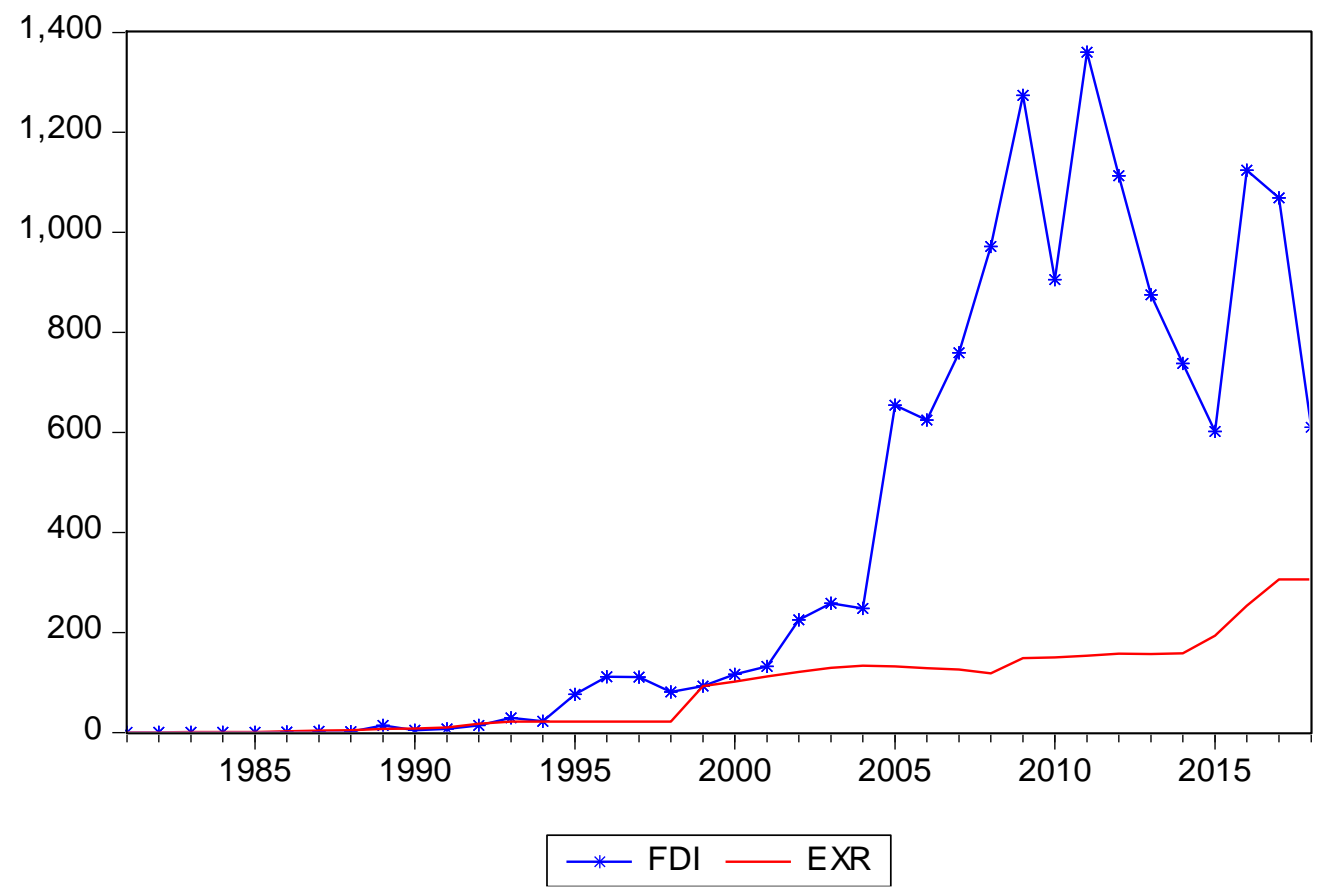

Source: E-View output data, 2019

Figure 3: Graphic representation of the FDI and EXR trend in Nigeria: 1981-2018

The trends shown in Figures 1, 2, and 3 revealed inverse relationship. Thus, as the exchange rate depreciates the FDI increased. From 1981 to 1985 the exchange rate was somewhat fixed and stable averaging $¥ 0.7 / \$ 1$, and the FDI was averaging $¥ 0.3$ billion. The FDI increased from 22.2billion in 1994 to $\$ 80.75$ billion in 1998, and the exchange rate was fixed at ₹21.8861/\$1.

In 2011, the FDI was at the highest peak of 1360.31billion when the exchange rate was $\$ 153.86 / \$ 1$. The recent FDI showed 1,124.15biliion (2016), $1,069.42$ (2017), and $\$ 610.38$ billion (2018). The exchange rates for the same period were $\$ 253.492,1305.79$, and \$306.0802 respectively. The surprising drop in the FDI in 2018 may not be unconnected to political crisis and increased hostility associated with dissatisfactions among the citizens and inadequate trust in the economy.

\subsection{Model estimation}

The lag structure investigation on the VAR model showed that AR roots were not stable. The estimated VAR is stable (stationary) if all roots have modulus less than one and lie inside the unit circle. Table 4 displayed the AR roots modulus. The AR in the first lag was 1.046764. The VAR estimate indicated non-stationarity of a modulus thus the VEC model was utilized in the study.

Table 4: Roots of Characteristic Polynomial: EXR FDI 


\section{International Journal of Social Sciences and Management Review}

\begin{tabular}{cc}
\hline \hline Root & Modulus \\
\hline \hline 1.046764 & 1.046764 \\
0.821733 & 0.821733 \\
0.143317 & 0.143317 \\
-0.122865 & 0.122865 \\
\hline \hline
\end{tabular}

Warning: At least one root outside the unit circle.

VAR does not satisfy the stability condition.

Source: E-view output data

The VEC estimates output data were indicated in Table 5.

Table 4: Vector Error Correction Estimates: EXR and FDI

\begin{tabular}{|c|c|c|}
\hline Cointegrating Eq: & CointEq1 & \\
\hline $\operatorname{EXR}(-1)$ & 1.000000 & \\
\hline \multirow[t]{2}{*}{ FDI $(-1)$} & \multicolumn{2}{|l|}{$\begin{array}{r}-0.166023 \\
(0.04009)\end{array}$} \\
\hline & \multicolumn{2}{|l|}{$[-4.14086]$} \\
\hline C & \multicolumn{2}{|l|}{-22.86983} \\
\hline Error Correction: & $\mathrm{D}(\mathrm{EXR})$ & $\mathrm{D}(\mathrm{FDI})$ \\
\hline \multirow[t]{3}{*}{ CointEq1 } & 0.024100 & 1.930640 \\
\hline & $(0.09222)$ & $(0.97265)$ \\
\hline & {$[0.26133]$} & [ 1.98492$]$ \\
\hline \multirow[t]{2}{*}{$\mathrm{D}(\mathrm{EXR}(-1))$} & $\begin{array}{c}0.324206 \\
(0.20931)\end{array}$ & $\begin{array}{r}-3.250245 \\
(2.20755)\end{array}$ \\
\hline & [ 1.54896$]$ & {$[-1.47233]$} \\
\hline \multirow[t]{2}{*}{$\mathrm{D}(\operatorname{EXR}(-2))$} & $\begin{array}{r}-0.007722 \\
(0.23087)\end{array}$ & $\begin{array}{r}-2.824971 \\
(2.43498)\end{array}$ \\
\hline & {$[-0.03345]$} & {$[-1.16016]$} \\
\hline \multirow{3}{*}{$\mathrm{D}(\mathrm{FDI}(-1))$} & -0.008290 & -0.159061 \\
\hline & $(0.01990)$ & $(0.20991)$ \\
\hline & {$[-0.41653]$} & {$[-0.75777]$} \\
\hline \multirow[t]{2}{*}{$\mathrm{D}(\mathrm{FDI}(-2))$} & -0.033641 & -0.102595 \\
\hline & $\begin{array}{r}(0.01918) \\
{[-1.75371]}\end{array}$ & $\begin{array}{r}(0.20232) \\
{[-0.50709]}\end{array}$ \\
\hline \multirow[t]{2}{*}{ C } & $\begin{array}{l}7.287347 \\
(3.70099)\end{array}$ & $\begin{array}{l}74.33037 \\
(39.0344)\end{array}$ \\
\hline & [ 1.96903$]$ & [ 1.90423$]$ \\
\hline
\end{tabular}




\section{International Journal of Social Sciences and Management Review}

Volume: 03, Issue: 04 "July - August 2020"

ISSN 2582-0176

\begin{tabular}{lrr} 
R-squared & 0.193958 & 0.220200 \\
Adj. R-squared & 0.054986 & 0.085752 \\
Sum sq. resids & 9179.166 & 1021087. \\
S.E. equation & 17.79109 & 187.6430 \\
F-statistic & 1.395658 & 1.637808 \\
Log likelihood & -147.1264 & -229.5809 \\
Akaike AlC & 8.750078 & 13.46176 \\
Schwarz SC & 9.016709 & 13.72840 \\
Mean dependent & 8.724459 & 17.43193 \\
S.D. dependent & 18.30136 & 196.2458 \\
\hline \hline & & \\
\hline \multirow{2}{*}{ Determinant resid covariance (dof adj.) } & 10189397 \\
Determinant resid covariance & 6995333. \\
Log likelihood & -375.1389 \\
Akaike informationcriterion & 22.23651 \\
Schwarzcriterion & 22.85865 \\
\hline \hline
\end{tabular}

Source: E-View output data, 2019

Diagnostic tests of the estimates

i. Lag structure investigation: The VEC stationarity test as indicated in Table 6 revealed that the variables are stable because all the modulus have statistics below 1.000.

Table 6: VEC stationarity test: EXR FDI

\begin{tabular}{ll}
\hline \hline Root & Modulus \\
\hline \hline 1.000000 & 1.000000 \\
$0.764753-0.229205 \mathrm{i}$ & 0.798363 \\
$0.764753+0.229205 \mathrm{i}$ & 0.798363 \\
$-0.126378-0.588554 \mathrm{i}$ & 0.601969 \\
$-0.126378+0.588554 \mathrm{i}$ & 0.601969 \\
-0.408036 & 0.408036 \\
\hline \hline
\end{tabular}

VEC specification imposes 1 unit root(s). Source: E-View output data, 2019

ii. Normality Tests

Table 7: VEC Residual Normality Tests

\begin{tabular}{lllll} 
Component & Skewness & Chi-sq & Df & Prob. \\
\hline \hline 1 & 2.211532 & 28.53010 & 1 & 0.0000 \\
2 & 0.527033 & 1.620291 & 1 & 0.2031 \\
\hline \hline Joint & & 30.15039 & 2 & 0.0000 \\
\hline \hline \multirow{2}{*}{ Component } & Kurtosis & Chi-sq & df & Prob. \\
\hline \hline 1 & 8.240868 & 40.05560 & 1 & 0.0000 \\
2 & 4.072352 & 1.676993 & 1 & 0.1953 \\
\hline \hline Joint & & 41.73259 & 2 & 0.0000 \\
\hline \hline
\end{tabular}




\section{International Journal of Social Sciences and Management Review}

Volume: 03, Issue: 04 “July - August 2020"

ISSN 2582-0176

\begin{tabular}{lrrr} 
Component & Jarque-Bera & df & Prob. \\
\hline \hline 1 & 68.58570 & 2 & 0.0000
\end{tabular}

Given the significance values (0.0000) of the joints: skewness, kurtosis and Jarque-Bera we conclude that the variables: Foreign exchange rate and Foreign Direct Investment were normally distributed.

Table 8: VEC Residual Heteroskedasticity Tests

VEC Residual Heteroskedasticity Tests: No Cross Terms (only levels and squares)

Date: 01/16/20 Time: $15: 14$

Sample: 19812018

Included observations: 35

Joint test:

\begin{tabular}{ccc}
\hline \hline Chi-sq & df & Prob. \\
\hline \hline 32.44184 & 30 & 0.3473 \\
\hline \hline
\end{tabular}

Individual components:

\begin{tabular}{cccccc}
\hline \hline Dependent & R-squared & $F(10,24)$ & Prob. & Chi-sq(10) & Prob. \\
\hline \hline res1*res1 & 0.084622 & 0.221867 & 0.9914 & 2.961756 & 0.9823 \\
res2*res2 & 0.673151 & 4.942840 & 0.0006 & 23.56028 & 0.0089 \\
res2*res1 & 0.189567 & 0.561378 & 0.8285 & 6.634830 & 0.7594 \\
\hline \hline
\end{tabular}

Source: E-View output data, 2019

\subsection{Hypothesis testing}

The paper hypothesized that Foreign Exchange Rate Fluctuations do not granger cause Foreign Direct Investment in Nigeria. Using the Granger causality test, the work tested the hypothesis as displayed in Table 9.

Table 9: VEC Granger Causality/Block Exogeneity Wald Tests 


\section{International Journal of Social Sciences and Management Review}

\begin{tabular}{|c|c|c|c|}
\hline \multicolumn{4}{|c|}{$\begin{array}{l}\text { VEC Granger Causality/Block } \\
\text { Date: } 01 / 16 / 20 \text { Time: } 15: 12 \\
\text { Sample: } 19812018 \\
\text { Included observations: } 35\end{array}$} \\
\hline \multicolumn{4}{|c|}{ Dependent variable: $\mathrm{D}(\mathrm{EXR})$} \\
\hline Excluded & Chi-sq & df & Prob. \\
\hline $\mathrm{D}(\mathrm{FDI})$ & 3.123126 & 2 & 0.2098 \\
\hline All & 3.123126 & 2 & 0.2098 \\
\hline \multicolumn{4}{|c|}{ Dependent variable: $\mathrm{D}(\mathrm{FDI})$} \\
\hline Excluded & Chi-sq & df & Prob. \\
\hline $\mathrm{D}(\mathrm{EXR})$ & 3.846478 & 2 & 0.1461 \\
\hline All & 3.846478 & 2 & 0.1461 \\
\hline
\end{tabular}

Source: E-View output data, 2019

Given the Chi-square values of 3.123, at 2 degrees of freedom, and Prob. (0.2098) for the dependent variable: Exchange rate; as well as for the Foreign Direct Investment of 3.846 and Prob. (0.1461) we conclude that Foreign exchange rate fluctuations and Foreign Direct Investment do not Granger cause each other in Nigeria.

\subsection{DISCUSSION OF FINDINGS}

This result of this study did not agree with the results of the related work of Goldberg and Kolstad (1995) which showed that increased exchange rate uncertainty has a positive impact on FDI. They noted that real exchange rate variability increased the share of total U.S investment capacity located in Canada and Japan and increased the share of Canadian and UK investment situated in the United States. It seems that the effect arises from mutual beneficial bilateral agreements among the concerned nations.

The Central Bank of Nigeria has actually displayed dexterity in foreign exchange management in recent times. The exchange rate targeting exhibited relative stability, the FDI has not been sustained perhaps due to deficiencies in the investment environment. Obviously, the exchange rate volatility would not have had any significant relationship with the FDI given that pressure on the exchange rate in Nigeria was mainly from commerce related transactions and tourism. The general economic and fiscal structure of Nigeria is somewhat majorly imbalance patriotism. The result is a widely accepted imperfectly competitive market and "sacred goat"/pampered market. The foreign exchange market is not speared. The intermediating agents consist mainly of the Central Bank of Nigeria serving as primary intermediation agent, parallel market/black market, inter-bank market, Bureau D'Changes and other fringe firms. 


\section{International Journal of Social Sciences and Management Review}

The foreign exchange rate stability, however, is needful for commercial viability of any FDI. The FDI will usually respond to sustainable investment environment and policies set in place by the Government. Typical investors are primarily driven by pecuniary value. Combined position of the macroeconomic fundamentals such as leadership and security, good governance, inflation, interest rate, ease of doing business, and exchange rate, therefore, are drivers of investment generally and FDI in particular.

\subsection{SUMMARY OF FINDINGS}

This study examined the relationship between foreign direct investment and foreign exchange rate from 1981 to 2018. The findings revealed the following:

1. Foreign direct investment has no significant effect on the exchange rate in Nigeria, but the exchange rate positively and significantly relates to foreign direct investment.

2. There is no granger causality existing between foreign exchange rate and foreign direct investment in Nigeria.

\subsection{CONCLUSION}

It is evident that foreign exchange rate related to foreign direct investment but has not significantly affected foreign direct investment in Nigeria. But, in addition to other investment environment factors combined optimally, adequate FDI will be attracted to Nigeria. Though there seems to be evidence of increasing capacity to grow and consume in Nigeria, structural deficiency has retarded sustainable growth and flow of FDI in Nigeria.

\subsection{RECOMMENDATIONS}

In lieu of the findings of this study, the following recommendations are put forward for consideration by concerned authorities:

1. The Central Bank of Nigeria should sustain the foreign exchange rate policies especially by financing commercial farming and agro-allied businesses and encouraging the standardization of products for exports. This will earn additional foreign exchange to the country thereby appreciating the value of local currency naira. Available foreign currency should be allocated mainly to export-oriented businesses.

2. The government should strive to reduce the cost of doing business by providing the necessary incentives that could stimulate the flow of foreign direct investment in Nigeria. Fully standardized Free trade zones and industrial layout should be marked out across the nations and private sectors should be encouraged to power the zones and layouts.

3. All levels of governments say the local, state and federal should work towards entrenching true federalism primarily designed to promote national interests and patriotism instead of parochial interest which has encouraged sectarian corruption and inefficiencies in foreign exchange management in Nigeria. 


\section{International Journal of Social Sciences and Management Review}

Volume: 03, Issue: 04 "July - August 2020"

ISSN 2582-0176

\section{REFERENCES}

Amisano, G. \& Carlo, G. (1997). Topics in Structural VAR Econometrics, $2^{\text {nd }}$ ed., Berlin: Springer-Verlag.

Adeolu, B. A. \& Simon, B. (2004). Direct foreign investment and firm level productivity in the Nigerian agro-allied sector. Journal of Social Science, 9(1), 29-36.

Adeseyoju, A. (2001, October 1). Attracting foreign investors to Nigeria. Daily Times of Nigeria

Adigwe, P. K., Ezeagba, C. E. \& Ude, F. P. (2015). Effect of foreign direct investment on Nigerian economic Growth. (2008-2013). European Journal of Research and Management Science, 4(5), 23-50.

Aitken, B., Hanson, G. H. \& Harrison, A. E. (1997). Spillovers, foreign investment and export behaviour. Journal of International Economics, 43(1 -2), 1 03-1 32.

Akeoraoghu, A. (2000). International capital movements, external imbalances and economic growth: the case of Turkey. Yapi Kredi Economic Review, 11(2), 2136.

Amadi, S. N. (2002). The impact of macroeconomic environment on foreign direct investment in Nigeria. International Journal of Development, 4(2), 352-361.

Aranyarat, C. (2010). The effect of exchange rate volatility on foreign direct investment and portfolio flows to Thailand. International Journal of Development, 2(2), 135-145.

Aremu, J. A. (2003). An Overview of Foreign Private Investment in Nigeria. Proceedings of the Twelfth Annual Conference of the CBN Regional Research Unit. Kaduna, Nigeria.

Asogwa, F.O., Okeke, J. M. \& Urama, S. M. (2013). The Impact of exchange rate dynamics on capital inflows in Nigeria. International Institute for Science, Technology and Education, 3(8), 50-61.

Athukorala, P. \& Rajapatirana, S. (2003). Capital inflows and the real exchange rate: A comparative study of Asia and Latin America. Journal of Humanities, 1(3), 45-60.

Ayanwale, A. (2007). Foreign direct investment and economic growth: evidence from Nigeria. AERC Research Paper. No.165.

Bekaert, G. \& Harvey, E. (1998). Market integration and investment barriers in emerging market equity returns. NBER Working Paper, N0:666.

Berument, H. \& Dincer, N. N. (2004). Do capital flows improve macroeconomic performance in emerging market? The Turkish experience. Emerging Market Finance and Trade, 40(4), 20-32. 


\section{International Journal of Social Sciences and Management Review}

Biiger, N. (1979). Exchange rate implication of international portfolio diversification. Journal of International Business Studies, 10, 64-74.

Blommenstein, H. (1998). Impact of Institutional investors on financial market. Institutional investors in the new financial landscape, Paris, France.

Blomstrom, M. \& Kokko, A. (1998). Multinational corporation and spill over. Journal of Economic Survey, 12, 57-68.

Blonigen, B. (1999). In search of substitution between foreign production and export. Journal of International Economics, 53, 81-104.

Blonigen, B. (2005). A review of the empirical literature on FDI determinants. NBER Working Paper No. 1229.

Campa, J. M. (1993). Entry by foreign firms in the United States under exchange rate uncertainty. Review of Economics and Statistics, 75, 614-622.

Central Bank of Nigeria (2017).Central Bank of Nigeria Statistical Bulletin. Abuja, Nigeria:

Central Bank of Nigeria Publication.

Corsetti, G. \& Konstantinou, P. (2009). What drives U.S foreign correlation in stock returns. Quarterly Journal of Economics, 108, 905-939.

Cushman, D. O. (1985). Real exchange rate risk, expectations and the level of direct investment. Review of Economics and Statistics, 67(2), 297-308.

Dacin, M. T., Ventresca, M. \& Beal, B. (1999). The embeddedness of organizations: dialogue and direction. Journal of Management, 25(3), 317-356.

Dimaggio, P. \& Powell, W. (1983). The iron cage revisited institutional isomorphism and collective rationality in organization fields. American Sociological Review, $48(2), 147-160$.

Dixit, A.K. \& Pindyck, R. S. (1994), Investment under uncertainty. International Economic Review, 36, 855-873.

Doan, D. (2010). FDI and economic growth in developing countries: the growth effects of vertical, horizontal and export platform FDI.

Doh, J., Rodriguez. L. \& Eden, L. (2003). Coping with corruption in foreign market. Academy of Management Executive, 17(3), 114-127.

Dadush, U., Dasgupta, D. \& Ratha, D. (2000). The role of short-term debt in recent crisis. Finance and Development, 37(4), 50-69. 


\section{International Journal of Social Sciences and Management Review}

Eden, L., Levita, E. \& Martinez, R. (1997). The production, transfer and spillover of technology. Small Business Economics, 9 (1), 53-66.

Eichengreen, B. \& Mussa, M. (1998). Capital account liberalization: theoretical and practical aspects. IMF Occasional Paper, No 172.

Esheneke \& Oriavwote (2014). An Empirical Assessment of Financial Sector Development and Economic Growth in Nigeria" International Review of management and Business Research, 3(1).

Ethier, W.J. (1982). National and international returns to scale in the modern theory of international trade. American Economic Review, 73, 389-405.

Eun, C. S. \& Resnick, B. G. (1988). Exchange rate uncertainty, forward contracts, and international portfolio selection. Journal of Finance, 43, 197-215.

Foad, H. S. (2005). Exchange rate volatility and export oriented FDI. Emroy University, Atlanta, G A.

Frankel, J. (2006). What do economists mean by globalization Implications for Monetary Policy? Froot, K. A. \& Stein, J. C. (1991). Exchange rates and foreign direct investment: an imperfect capital market approach. Quarterly Journal of Economics, 106 (4), 58-69.

Froot, K. A., O'Connell, P. G. \& Seasholes, M. (2001). The portfolio flows of international investors. Journal of Financial Economic, 59, 151-193.

Goldberg, L .S. \& Kolstad. C. D. (1995). Foreign direct investments exchange rate variability, and demand uncertainty. International Economic Review, 36, 855-87 3.

Hausmann, R. \& Fernandez-Ariaz, E. (2000). foreign direct investment: good cholesterol? IDE Working Paper, No. 348.

Hongxin, J. Z., Kim, S. H. \& Du, J. (2003). The impact of corruption and transparency on foreign direct investment: an empirical review. Management International Review, 43(1), 41-62.

Horstmann, I. J. \& Markusen, J. R. (1992). Strategic investment and development of multinational. International Economic Review, 82,186-190.

Hymer, S. H. (1960). The International Operations of National Firms: A Study of Direct Foreign Investment. Cambridge: MIT Press.

Ikiara, M. M. (2003). Foreign direct investment, technology transfer, and poverty alleviation: Africa's hopes and dilemma. African Technology Policy Studies Network (ATPS) Special Paper Series No. 16, Nairobi, Kenya. 


\section{International Journal of Social Sciences and Management Review}

Volume: 03, Issue: 04 "July - August 2020"

ISSN 2582-0176

International Monetary Fund. (2005, September). Global Financial Stability Report.

International Monetary Fund (1999). Growth in Sub-Saharan African: performance, impediments and policy requirements. World Economic Outlook. Chapter 4.

Jhingen, M. L. (2007). Macroeconomic Theory, $11^{\text {th }}$ revised edition. India: Vrinda publication.

Kinoshita, Y. \& Mody, A. (1997). Private and public information for foreign investment decision. World Bank Policy Research Work paper, No. 1733.

Kokko, A. (1996). Productivity spillovers from competition between local firms and foreign affiliates. Journal of International Development, 8(4), 517 - 530.

Konings, J. (2001). The effects of FDI on domestic firms: evidence from firm level panel data in emerging economies. Economics of Transition, 9(3), 619 - 633.

Kostova, T. \& Roth, K. (2002). Adoption of an organizational practice by multinational corporations. Academy of Management Journal, 45(1), 215-233.

Lall, S. (1980). Vertical inter-firm linkages in Ides: An empirical study. Oxford Bulletin of Economic Statistics, 42, 13-30.

Lipsey, R. \& Wleiss, M. Y. (1981). Foreign production and export in manufacturing industries. Review of Economic and Statistic, 63, 488-494.

Lipsey, R. E. (2001). Foreign direct investors in three financial crises. NBER Working Paper, No. 8084.

lyoha, M. I. (2002). An econometric study of the main determinants of foreign investment in Nigeria. The Nigeria Economic and Financial Review, 6 (2).

lyoha, M. A. \& Unugbro, A. O. (2005). International Trade and Finance. Revised Edition, Benin City: Mindex Publishing.

Macaulay, E. D. (2012). Foreign direct investment and the performance of the Nigerian economy. Journal of International Development, 9(1), 117 - 130.

Mallampally, P. \& Sauvant, K. P. (1999). Foreign direct investment in developing countries. Finance and Development, 36(1), 8-15.

Moghalu, K. (2009). Strategic approach to foreign investment in Nigeria. A paper presented in the Business and investment forum for Nigerian Governors, Abuja Nigeria.

Mwilima, N. (2003). Characteristics, extend and impact of foreign direct investment on African local economic development, Social Science Research Network electronic paper collection. Retrieved from http://ssrn.com.

North, D.C (1991). Institutions, institutional change and economic performance. Princeton Publishers. London 


\section{International Journal of Social Sciences and Management Review}

Nucci, F. \& Pozzolo, F. (2001). Investment and the exchange rate: an analysis with firm level panel date. European Economic Review, 45, 259-283.

Nurudeen, G. A. (2010). Determinants of foreign direct investment in Nigeria: an empirical analysis. Global Journal of Human Social Science, 10(1), 56-65.

Obadan, M. I. (1982). Direct investment in Nigeria: an empirical analysis. African Studies Review, 25, 91-100.

Obaseki, P. J. (1991). Foreign exchange management in Nigeria: past, present and future. CBN Economic and Financial Review, 29(1), 30-41.

Obstfield, M. (1994). Risk-taking, global diversification and growth. American Economic Review, 84(5), 1310-1329.

OECD (2002). Foreign portfolio and direct investment: complementarily, differences and integration. African Economic Research, 9(9), 8-15.

Ojo, M. O. (2003). Foreign exchange management strategies under Nigeria's Structural Adjustment Programme. CBN Bulletin, 24, 3-20.

Okafor, H. O. \& Arowoshegbe, A. O. (2011). Stimulating economic development through the capital market: the Nigerian experience. Journal of Management, 1(2), 23-46.

Oliver, C. (1997). Sustainable competitive advantage: combining institutional and resource-based view. Strategic Management Journal, 18(9), 697-713.

Omankhanlen, A. E. (2011). Foreign direct investment and its effect on the Nigeria economy. (1980-2009). Business Intelligence Journal, 8(6), 1-12.

Patro, D. \& Wald, P. (2005). Firm characteristics and the impact of emerging market liberalization. Journal of Banking and Finance, 29(1), 1671169

Philips, S. \& Fredoun, Z. A. (2008). Exchange rates and foreign direct investment: theoretical models and empirical evidence. The Australian Journal of Agriculture and Resource Economics, 52, 505-525.

Prakash, L. \& Assaf, R. (2001). How beneficial is foreign direct investment for developing countries? Finance and Development, 38(2), 89-100.

Prasad, S. E., Rajan, R. G. \& Subramanian, A. (2007). Foreign capital and economic growth. Journal of International Development, 6(4), 217 - 230.

Ramirez, A. \& Kwok, C. (2006). Multinationalism as a moderator of national institutions: the case of culture and capital structure decision. CIBER Working Paper No. 634. 


\section{International Journal of Social Sciences and Management Review}

Roberts, M. \& Tybout, J. (1997). The decision to export in Columbia: an empirical model of entry with sunk costs. American Economic Review, 87, 545-564.

Rodriquez-Clare, A. (1996). Multinational linkages and economic development. American Economic Review, 86, 526-535.

Root, F. R. (1984). International Trade and Investment. $5^{\text {th }}$ Edn. Canada: South Western Publication Company.

Rodrick, D. (1998). Who needs capital account convertibility? Essays in International Finance N0. 207.

Saggi, K. (2002). Trade, foreign direct investment and international technology transfer: a survey. World Bank Research Observer, 17 (2), 199-235.

Scharfstein, D. (1988). The disciplinary role of takeovers. Review of Economic Studies, 55, 185-99.

Schleifer, A. \& Vishny, R. W. (1993). Corruption. Quarterly Journal of Economics, 108(3), 788-806.

Securities and Exchange Commission (2008). The implication of the 2006 budget for the capital market. Journal of Securities and Exchange Commission, 2, 91-95.

Servein, L. (2003). Real exchange rate uncertainty and private investment in LDCS. The Review of Economics and Statistics, 85, 212-218.

Shiro, A. A. (2009). The Impact of FDI on the Nigerian Economy. Paper delivered at the 2nd National Conference organized by the Department of Finance, University of Lagos, Lagos State. Retrieved from www.unilag.edu.ng/research view.

Solow, B. M. (1987). Economic Growth theory. American Economic Review, 73 (3), 307317.

Stiglit J.E. (1985). Credit markets and the control of capital. Journal of Money, Credit and Banking, 17(2), 133-152.

Stiglitz, J. E. \& Weiss, A. (1981). Credit Rationing in Markets with Imperfect Information. The American Economic Review 71, 393-410.

Tadaro, M. P. (1999). Economic Development. 7th Edition. Addison Webley: Longman Inc. Reading Massachusetts.

Todaro, M. P. \& Smith, S (2003). Economic Development. 8th ed. New Delhi India: Pearson Education.

Treisman, D. (2000). The causes of corruption: A cross-national study. Journal of Public Economics, 76, 399-457. 


\section{International Journal of Social Sciences and Management Review}

Ugwuegbe, U. O. \& John, I. (2013). Impact of Foreign Direct Investment on the Nigeria Economy. Journal of finance and accounting, 5(1), 121-134.

UNCTAD (1997). World Investment Report, United Nations New York.

UNCTAD (2006). World Investment Report, United Nation, New York.

United Nations Economic Commission for Africa (UNECA) (2006). Economic Report on Africa: Capital flows and developments financing in Africa, UNECA, Addis Ababa.

Vintila, F. (2010). Foreign direct investment theories: Overview of the main FDI theories. European Journal of Interdisciplinary Studies, 8(2), 1-15.

Westney, D. E. (1993). Institutionalization theory and the multinational corporation. In: S. J. Ghosha and D. E. Westney (Eds) Organization Theory and the Multinational Corporation. New York: St. Martin's Press.

Willianson, O. E. (1985). The economic institutions of capitalism. In Ahlquist, J. S. (2006). Economic policy, institutions and capital floors, International Studies Quarterly, 55, 69-70.

World Bank (1996). World Debt Tables: External Finance for Developing Countries. Washington DC: World Bank Publication.

Yong, T. A. \& Tang, T. C. (2009). The determinants of inward foreign direct investment: the case of Malaysia. Business and Economic Discussion Paper, 22(9), $70-85$. 
International Journal of Social Sciences and Management Review

Volume: 03, Issue: 04 "July - August 2020"

ISSN 2582-0176

\section{Appendix I}

Table 2: Data of Nigeria's Foreign Direct Investment and Foreign Exchange rate: 19812018

\begin{tabular}{|c|c|c|}
\hline YEAR & FDI (Billion Naira) & EXR (Naira/US Dollar) \\
\hline 1981 & 0.335 & 0.61 \\
\hline 1982 & 0.29 & 0.6729 \\
\hline 1983 & 0.2643 & 0.7241 \\
\hline 1984 & 0.3604 & 0.7649 \\
\hline 1985 & 0.4341 & 0.8938 \\
\hline 1986 & 0.736 & 2.0706 \\
\hline 1987 & 2.45 & 4.0179 \\
\hline 1988 & 1.72 & 4.5367 \\
\hline 1989 & 13.88 & 7.3916 \\
\hline 1990 & 4.69 & 8.0376 \\
\hline 1991 & 6.92 & 9.9095 \\
\hline 1992 & 14.46 & 17.2984 \\
\hline 1993 & 29.66 & 22.0511 \\
\hline 1994 & 22.20 & 21.8861 \\
\hline 1995 & 75.94 & 21.8861 \\
\hline 1996 & 111.29 & 21.8861 \\
\hline 1997 & 110.45 & 21.8861 \\
\hline 1998 & 80.75 & 21.8861 \\
\hline 1999 & 92.79 & 92.6934 \\
\hline 2000 & 115.95 & 102.105 \\
\hline 2001 & 132.43 & 111.943 \\
\hline 2002 & 225.22 & 120.97 \\
\hline 2003 & 258.39 & 129.357 \\
\hline 2004 & 248.22 & 133.5 \\
\hline 2005 & 654.19 & 132.147 \\
\hline 2006 & 624.52 & 128.652 \\
\hline 2007 & 759.38 & 125.833 \\
\hline 2008 & 971.54 & 118.567 \\
\hline 2009 & $1,273.82$ & 148.88 \\
\hline 2010 & 905.73 & 150.298 \\
\hline 2011 & $1,360.31$ & 153.86 \\
\hline 2012 & $1,113.51$ & 157.5 \\
\hline 2013 & 875.10 & 157.31 \\
\hline 2014 & 738.20 & 158.563 \\
\hline 2015 & 602.07 & 193.279 \\
\hline 2016 & $1,124.15$ & 253.492 \\
\hline 2017 & $1,069.42$ & 305.7901 \\
\hline 2018 & 610.38 & 306.0802 \\
\hline
\end{tabular}

Source: Central Bank of Nigeria Statistical Bulletin, 2019 